\title{
MODERN CRITICISMS TO NATURAL THEOLOGY AND SWINBURNE'S PROBABILISTIC APPROACH
}

\author{
Agnaldo Portugal \\ https:/ / orcid.org/0000-0003-4513-5374 \\ Universidade de Brasilia \\ Department of Philosophy \\ Brasilia, D.F. \\ Brazil \\ agnaldocp@unb.br
}

\author{
Article info \\ CDD: 200.1 \\ Received: 11.10.2021; Accepted: 08.11.2021 \\ https://doi.org/10.1590/0100-6045.2021.V44N4.AP \\ Keywords \\ Natural Theology \\ Inductive Approach \\ Hume \\ Kant \\ Richard Swinburne
}

\begin{abstract}
In this article I expound some of the main criticisms by David Hume and Immanuel Kant against the legitimacy of natural theology, the philosophical activity of presenting arguments for or against the existence of God. The aim is not to contribute to the scholarship in history of philosophy, but as a starting point for describing the main lines of Richard Swinburne's approach to natural theology in terms of inductive probabilistic arguments. His proposal has been part of a current philosophical movement of reestablishing the argumentative debate on the existence and nature of God, an area that has been growing in quantity and quality since the 1970's.
\end{abstract}




\section{Introduction}

Richard Swinburne is best known for his proposal of giving a new shape to the traditional enterprise of providing arguments for the existence of God. This new shape is captured by an inductive interpretation of a theorem of the probability calculus, named after the author of a paper on the probability of chances published in 1763, Rev. Thomas Bayes. Coincidently or not, it was just in the 18th century when the intellectual respectability of theism began to be put into question most seriously, particularly with the works of David Hume and Immanuel Kant. Natural theology since then has gradually fallen in disrepute in the main academic philosophical circles, particularly in continental Europe.

This article aims to focus on the answers that could be given to those criticisms in view of Swinburne's approach, which can overcome a general thesis that natural theology is no longer possible in an age of science.

\section{Hume, Kant and the Need for a New Natural Theology}

I had a strange feeling of mismatch when I started my BA in philosophy in Brazil in the second half of the 1980's. While Brazilian society and culture was deeply religious (mainly Christian and mostly Roman Catholic back then), the academic environment was curiously hostile to this human activity. In those days, the military dictatorship was coming to an end of a long period of more than two decades, and people could express their political views freely again. Marxism was then highly regarded among Brazilian philosophers, who saw liberation theology as an ally for changing the very unequal Brazilian society, despite the fact that it was, in the view of those philosophers, deeply 
mistaken in assuming the existence of a being that was simply the invention of the 'alienated consciousness' of the human genre. Things did not change very much as regards the general view of religion when a more diversified range of history of philosophy scholarship replaced the relative hegemony of Marxism in philosophy departments later on. Belief in God in a realistic sense was not only the 'opium of the people' anymore. Rather, it was - in addition, and among many other problems - an idea that had been refuted by the arguments of David Hume and Immanuel Kant in the $18^{\text {th }}$ century. In particular, so we were taught, these authors had shown that good old natural theology - the traditional philosophical activity of presenting arguments for and against the existence of God - was not good at all, just old. And this was not a Brazilian idiosyncrasy. In fact, that was a common view in the main circles of more established academic milieus in the West.

Yet, what was such a devastating challenge to natural theology and the justification of theistic belief by Hume and Kant? It is not an easy task to summarize their criticisms, but it is reasonable to attempt at least a justifiable interpretation of their accounts, particularly if we concentrate on their main texts on this regard. Hume's objections to natural theology are mostly in his Dialogues concerning Natural Religion (1779) and Kant's chief criticisms are located almost at the end of his monumental Critique of Pure Reason (1781 and 1787). Despite being both against natural theology, they have different focuses, which requires a separate analysis for each.

\subsection{Hume's (alleged) debunk of arguments to the belief in God}

As is widely known, Hume's Dialogues is a discussion among three characters on the legitimacy of treating the nature and existence of God in argumentative terms. 
Although it is not totally clear, it is very probable that the sceptical Philo is Hume's spokesman in a conversation that also includes Cleanthes (who defends the argument from design), and Demea (who rejects empirical arguments for God, and offers an a priori one instead). Given the prevalence of the sceptical approach, we can say that the aim is to show that arguments for the existence of God are all doubtful, and that the uncertainty they generate can be harmful to religious practice. This is so because, just before the final declaration of who won the debate, Philo asserts that a sceptical attitude regarding the limits of human reason takes the educated man to revealed religion.

On the other hand, Philo criticizes those who believe they can be sure of philosophical concepts, since they generally disdain of common religion. So, he asserts at the end of the book: "to be a philosophical sceptic is, in a man of letters, the first and most essential step towards being a sound, believing Christian" (Hume D 12.33, KS 227-8) ${ }^{1}$. If Hume's position was really a defence of Christianity or amounted to a disguised atheism is a matter of contention for this author's scholarship, which does not need to detain us here. I suggest that we focus on the challenges his book posed on natural theology in order to see how Swinburne's work could be seen as an answer to that challenge.

Philo's objections to Cleanthes' argument can be summarised in two basic contentions. On the one hand, Hume argues that the analogy between God and the human mind is too weak, given that God is essentially non-corporeal and infinite, while the human mind is physically connected to a brain (it is just 'a little agitation' of it) and finite. On the other hand, why should the human mind be the model for the origin of the whole universe? Why not other explanatory

1 The source of Hume's works I am using here is Hume's Texts Online (https:/ / davidhume.org/texts accessed on April 4, 2020).

Manuscrito - Rev. Int. Fil. Campinas, v. 44, n. 4, pp. 564-606, Oct.-Dec. 2021. 
hypotheses? These are problems not only to this type of argument, but may be taken to be a challenge to all a posteriori inferences which aim to draw a conclusion about the existence of God.

The second problem mentioned in the previous paragraph took Hume to raise many different alternative hypotheses to theism in order to explain the origin of the physical universe. Each one could have in its support a desirable feature for an a posteriori explanation. We had then the possibility of many limited deities working together, each one in a part or particular feature of the universe (Hume D 5.8, KS 167-8). This would resemble more closely the way human beings build up an intentional designed construction, i.e., by collaborative work. The hypothesis of a child deity, who left his unfinished work behind due to her incompetence (Hume D 5.12, KS 168-9), would explain the apparently unsatisfactory features of the world and this way it would be a solution to the problem of evil. The idea of God as the soul of the universe (Hume D 6.3, KS 170-1) - a kind of pantheism perhaps - would be closer to the analogy with the human mind, since this one is not seen as disconnected from a brain. The conjecture of the world as an animal or a vegetable generated organically (Hume D 7.3, KS 176-7) would equally explain the existence of the physical universe, with the advantage of not postulating any entity besides the natural world itself. This simplicity would also be the advantage of the atomistic hypothesis, according to which all is matter and movement with no intentional guiding force (Hume D 8.2, KS 182).

The proliferation of hypotheses shown above indicates for Hume the main problem with natural theology, namely, its lack of empirical basis. In agreeing with Demea, who protests against the arbitrariness of the explanations proposed, Philo claims: 
This is the topic on which I have all along insisted. I have still asserted that we have no data to establish any system of cosmogony. Our experience, so imperfect in itself, and so limited both in extent and duration, can afford us no probable conjecture concerning the whole of things. (Hume D 7.8, KS 177)

In other words, the main problem with natural theology and its alleged explanatory power is that it has no basis on experience and, as Philo asserts somewhere else 'Every event, before experience, is equally difficult and incomprehensible; and every event, after experience, is equally easy and intelligible' (Hume D 8.4, KS 182-3)².

So, Hume's challenge to natural theology could be summarised in the following points:

- Why would God be a better stopping-point of explanation than the physical universe?

- How can theism be an explanatory hypothesis if God is such an obscure concept?

2 Additional quotations to reinforce this idea are: ‘... who can retain such confidence in this frail faculty of reason as to pay any regard to its determinations in points so sublime, so abstruse, so remote from common life and experience?' (Hume D 1.3, KS 131-2); 'Our ideas reach no farther than our experience: We have no experience of divine attributes and operations; I need not conclude my syllogism; You can draw the inference yourself (Hume D 2.4, KS 142-3). See also Philo's objection that empirical induction is not possible in this case, because we are talking about objects like God (of which we have no experience) and the origin of the universe (which was a singular event) (Hume D 2.24, KS 149-50).

Manuscrito - Rev. Int. Fil. Campinas, v. 44, n. 4, pp. 564-606, Oct.-Dec. 2021. 
- What would prevent us of making up as many wild hypotheses we wanted?

- Why not alternative explanations to theism such as a finite God, multiple deities, pantheism?

- How could we accept any theoretical effort that is so distant from experience and so beyond the limits of the human cognition?

As we will see in the next subsection, this last questioning by Hume is also the main criticism made by Kant to the effort of arguing to God rationally. There are other similarities, but also some new problems that should be addressed by a proposal like the one held by Swinburne. Let us then have a look at what Kant objected to natural theology.

\subsection{Kant and the critique of natural theology}

While Hume's Dialogues are concerned with the limits of reason regarding religion, Kant's first Critique deals with the extension to which pure reason can provide knowledge in metaphysics. For Hume, human reasoning is too fallible to be able to settle matters in a subject so complex and as important as religion. Natural theology can do more harm than good, since it falls short of the power of demonstrative reason we found in mathematics and the cognitive clarity we encounter in empirical sciences. In the end, natural theology may only leave us in the dark, since it promises something that it cannot deliver, and when the support to religion is perceived as feeble, it can have the undesirable side effect of weakening faith. Kant seems to be discussing something very different, related to what it is that confers legitimacy to an area of knowledge. It is true, Kant also thinks his critical 
work will also be beneficial to religion in responding to the danger of scepticism or at least will do no harm to common people's faith, since what is done in the academic environment does not affect in the least 'the public mind' (Kant, Critique of Pure Reason, B xxxii). Largely, however, while Hume is doing philosophy of religion, Kant is doing epistemology or philosophy of science. Even so, considering the subject of our discussion, they have many points in common.

Kant understands metaphysics as an area of inquiry that deals with concepts alone, in the sense that they are not derived from experience, but come from pure reason speculation (B xiv). Like Hume, Kant also takes empirical sciences and mathematics as models for comparison. In view of them, metaphysics is highly problematic and unsatisfactory since there is never agreement about any important subject in this area. His proposal to change this pitiful situation is to limit our knowledge to what is accessible to experience. And experience has to do to what appears to our sensibility, not to what things are in themselves, which is something beyond the limits of what we can know. Matters like freedom, immortality and God - the main metaphysical matters according to him - are clear examples of something that is beyond the limits of what appears to our sensibility and, as a result, of what we cannot know (B xxx).

For Kant, although all knowledge about the world begins with experience (which from what he says most of the time should be sensorial only), it does not arise out of experience. Sensible impressions have to be added up with something from our own faculty of knowledge in order to provide us with empirical knowledge. This addition that is independent of experience is called a priori. However, propositions like 'every alteration has its cause' is a priori, but not purely so, since alteration is an empirical concept (Kant, Critique of Pure Reason, B 3). A first criterion for considering a proposition 
purely a priori is that whose thought is necessary or is derived from a necessary judgement. Necessity for him is a quality of a sentence, which is a language construction. A sentence is necessary when its negation would imply a logical contradiction. A second criterion for being a priori is universality, when a predicate is applicable to all objects of a certain set, like in 'all men are mortal'. There are some elements of empirical concepts that are not derived from experience, but that remain even if we remove all empirical additions to them. These elements (like being a substance or being caused) consist of a priori knowledge. In other words, empirical knowledge is made of a synthesis between a form given by concepts and a content given by experience. In a famous statement to summarise this idea, Kant affirms: 'Thoughts without content are empty, intuitions without concepts are blind...The understanding can intuit nothing, the senses can think nothing' (B 75).

Now where does natural theology stand in all this discussion? For Kant, this is part of metaphysics and metaphysics deals with ideas that have nothing to do with experience. So, natural theology cannot be a type of knowledge like physics, which is a synthesis between the intuitions provided by the senses and the concepts given by a priori concepts. Metaphysics is a matter of pure reason, and 'the propositions of pure reason, especially if they venture out beyond all limits of possible experience, cannot be brought to the test through any experiment with their objects, as in natural science' (Kant, Critique of Pure Reason, B xix). As we will see shortly, for Kant, God transcends 'the limits of possible experience' and cannot be object of empirical knowledge. On the other hand, he does not deny that there are types of knowledge that are independent of experience, like mathematics. Yet, natural theology would be a priori, but not in the sense that geometry or algebra are a priori. Differently from logic (in Kant's time at least), mathematics 
is a science that amplifies our knowledge even not being related to sense experience. Because it is an exact science, mathematical propositions are universal (they apply to all cases) and independent of what is captured by our senses. Mathematics is a type of amplifying knowledge because it relates to a non-sensorial kind of experience. He calls this non-sensorial kind of experience 'pure intuition' (B 35), and it refers to the concepts of space and time, which are conditions for us to perceive something in the world. So, mathematics is a knowledge related to the experience of our own forms of sensing things in the world. Since space and time are forms of our own capacity of perceiving things, not sensorial objects, they are independent of the imprecise experience we have of the world outside ourselves. On the other hand, given that these forms are experienced by us as intuitions, space and time are the fundamental objects about which mathematical knowledge is made of (B 44). As a result, while logic is purely formal, both physics and mathematics are related to a type of experience, and since natural theology refers to God, who is beyond all possible experience, it cannot be considered a legitimate type of knowledge.

So, in the end, Kant's basic objection against natural theology in the Critique of Pure Reason was the same as Hume's in the Dialogues: God is beyond the reach of any possible experience. Hence, given that we only have amplifying knowledge of matters of experience, natural theology is not a type of knowledge. Now, notice that, in contrast with Hume, Kant admits a kind of non-sensorial experience to explain mathematics. And his notion of 'fact of reason' that appears in the Critique of Practical Reason (1788) seems to indicate that he would admit even another type of experience, namely, the consciousness of moral good, which grounds the righteousness of moral actions - why it is good to act morally. One becomes aware that we should do what is good through a kind of experience, analogous to hearing a 
voice telling us so. However, if sense experience is not the only one that is possible, why not to allow for religious experience, the perception of God's presence, which so many people report to have had in human history? As I briefly mentioned above, for Kant God cannot be perceived in experience because $\mathrm{He}$ is the ens realissimum, which is by definition beyond the reach of sense experience. But this is not the question. Why not admitting another type of experience, apart from the sensorial, the mathematical and the ethical?

Why not a religious experience in which people have at least a partial awareness of God's presence? There is not really an answer to this question in Kant's writings as far as I could gather; the most you will find is the rejection of religious experience as resulting from fanaticism in a latter book by him called Religion Within the Limits of Reason Alone (1794), which is not exactly an argument, at least a good one. The idea behind it is not very clear, but it seems to be that religious experience is a subjective mental state, with no cognitive value. This is highly debatable, but we are not going to discuss it now. So, despite giving the impression of enlarging the notion of experience so as to make sense of mathematics and ethics, Kant agrees with Hume in objecting to natural theology because it is beyond the empirical limits.

Now, there is an important innovation in Kant's criticism to natural theology, which we do not find in Hume's Dialogues. For Kant, there are only three types of possible arguments to God:

All the paths leading to this goal [of proving the existence of God by means of speculative reason] begin wither from determinate experience and the specific constitution of the world of sense as thereby known, and ascend from it, in accordance with laws of causality, to 
the supreme cause outside the world; or they start from experience which is purely indeterminate, that is from experience of existence in general; or finally they abstract from all experience, and argue completely a priori; from mere concepts, to the existence of a supreme cause. The first proof is the physictheological, the second the cosmological, the third the ontological. There are, and there can be, no others. (B 618-9)

Kant was the responsible for giving the name 'ontological' to the argument first put forward by Anselm of Canterbury in the $11^{\text {th }}$ century. The Critique of Pure Reason analyses the version to it given by Descartes six centuries later. The ontological argument is considered by Kant the most important one, actually the only proof that can really do the job, being the other two totally dependent on it. Let us see how Kant justifies this thesis.

The first thing to consider here is that, for him, the object of theology is the highest condition of the possibility of all that can be thought (the being of all beings) (A 334). Pure reason furnishes then the idea for a transcendental knowledge of God (A 335), that is, as Kant says, in order 'to know a thing, we must know every possible predicate and must determine it thereby, either affirmatively or negatively' (B 601). In other words, reason employs a transcendental substrate to determine things. This substrate is the whole of all predicates, the ideal of unlimited 'all reality' (B 604), and this is the concept of an ens realissimum, as an individual being. 'This ideal is the supreme and complete material condition of the possibility of all that exists' (B 604). So, pure reason formulates the concept of a general background, which is condition for thinking each individual thing in particular. This idea of supreme reality would be the pure reason notion 
of God. It is to prove the existence of a being corresponding to this notion that the natural theology arguments are designed.

Now, the reason why the ontological argument is fundamental to the other ones is that these arguments must rest on the absolutely necessary, otherwise they will leave room for the question of what grounds God as the ground of empirical reality. God is here conceived as an unconditionally necessary being in order to be argued for as the ultimate foundation of all existing things. 'Accordingly, we conclude that the supreme being, as primordial ground of all things, must exist by absolute necessity' (B 615). Examples of necessity as something whose denial is contradictory are always of judgements, not of existing objects. Thus, it comes the ontological argument claiming that for the ens realissimum the conception of His nonexistence is contradictory with His own concept, since if $\mathrm{He}$ did not exist, He would not be the ens realissimum (B 624). Hence, the ontological argument concludes, God must exist necessarily. However, since all existential propositions may be false, there is no contradiction in denying the existence of God (B 626), and because of this Kant argues that the ontological argument is actually fallacious. As a result, he says:

Whatever, therefore, and however much our concept of an object may contain, we must go outside it, if we are to ascribe existence to the object. In the case of objects of the senses, this takes place through their connection with some one of our perceptions, in accordance with empirical laws. But in dealing with objects of pure thought, we have no means whatsoever of knowing their existence, since it would have to be known in a completely a priori manner. Our 
consciousness of all existence (whether immediately through perception, or mediately through inferences which connect something with perception) belongs exclusively to the unity of experience; any alleged existence outside this field, while not indeed such as we can declare to be absolutely impossible, is of the nature of an assumption which we can never be in a position to justify. (B 629)

So, a mere conceptual proof like the ontological argument will not be enough to show the existence of any being, even God. Still, only an argument like this would be able to show the necessity of God as the terminal point of a metaphysical argumentation about the foundations of reality. And this impossible situation shows to Kant that natural theology cannot actually be successful. Although the flaws of the ontological argument would be sufficient for Kant to settle the matter about the impossibility of any arguments to the existence of God, he went on in criticizing the other two arguments. Let us see some of these objections in order to evaluate to which extent Swinburne's proposal meets these criticisms.

The cosmological argument starts with an empirical premise about the existence of something indeterminate in the world, and then goes on to say that this existence must have been caused by something else. Lest we do not go on indefinitely from a finite cause to another finite cause, we must stop in an uncaused cause. This uncaused cause must be a necessary being, and this is why the cosmological argument is not an autonomous proof for Kant, but only a step to the ontological argument. Apart from this, Kant argues that the cosmological argument makes an illegitimate move, namely, to apply the concept of causality to something that is not perceivable by the senses: 
For the mere intellectual concept of the contingent cannot give rise to any synthetic proposition, such as that of causality. The principle of causality has no meaning and no criterion for its application save only in the sensible world. But in the cosmological proof it is precisely in order to enable us to advance beyond the sensible world that it is employed. (B 637)

It seems also that Kant thinks that human reason is not capable of grasping the concept of God: 'Unconditioned necessity, which we so indispensably require as the last bearer of all things, is for human reason the veritable abyss' (B 641). As a result, the cosmological argument does not work because the concept of a necessity that does not depend on anything else would be beyond our capacity of conception.

The third kind of proof Kant admits in his limited typology is the one from the empirical determinate existence of something in the world. The order found in a definite physical object is argued to be analogous to the intelligence found in human artefacts. The cause of this natural order, so the physic-theological argument goes, must be a necessary being that is not caused by anything else. We then fall in the ontological argument again. In addition to the difficulties indicated above, Kant argues that a substantive argument to God from the world order would require showing that the only way for the world to have order and harmony is by means of the intentional action of a supreme wisdom (B 655). And the analogy with human art would only prove at most the need of an architect limited by the matter with which he works, not a creator. Apart from this the arguments of speculative reason should 'provide the basis of a proof 
which may help us to attain to an assured conviction of a supreme being' (B 648). And the problem with the physictheological proof is that it is based on a determinate experience in the present world, and this can never satisfy or be equal to an idea, such as the idea of a necessary, unconditioned and all sufficient original being. This concept is too high above anything empirical, Kant argues. According to him,

This concept is in conformity with the demand of our reason for parsimony of principles; it is free from self-contradiction, and is never decisively contradicted by any experience; and it is likewise of such a character that it contributes to the extension of the employment of reason within experience, through the guidance which it yields in the discovery of order and purposiveness (B 651)

These requirements for a proper concept of God should be addressed by a natural theology, according to Kant. Actually, his criticisms along with those made by Hume were meant to show that this kind of intellectual activity should disappear. For them, this would have no impact on religion, since faith does not need any rational foundation. Both also agree that God is beyond any possible experience, and this is the main reason natural theology is no longer possible in an age of science. Its arguments are not forceful, they argued, since they cannot establish God's existence with certainty. The necessary being whose existence natural theology needed to prove cannot be shown by an a priori argument like the ontological, simply because this inference is not solid. 
In view of these objections, many philosophers thought natural theology would have no future. Although we still had the publication of Natural Theology by William Paley in 1802, which was widely popular until Darwin's time, the practice of proposing arguments to ground the belief in the existence of God was falling into discredit in the academic philosophical community from the second half of the $19^{\text {th }}$ century onwards. If natural theology were possible at all, there was a need for a new one.

\section{Natural Theology in a New Form: Responses to Hume and Kant}

The long and impressive history of natural theology as a philosophical activity was heavily questioned by Hume and Kant along the lines expounded above basically. In order to retake this enterprise one of the tasks to be accomplished is to answer those challenges, so that the credibility of arguing about God with arguments could be restored.

\subsection{Answering Hume}

Hume and Kant's objections were highly influential in modern philosophy and even modern theology. The upshot of their criticism was a sense that the belief in God was not a matter related to reason, at least not to the kind of reason we have in empirical sciences, one of the biggest achievements of modern times. While Kant still saw a place to God in a type of reason associated with ethics and the justification of moral action, Hume seemed to relegate religious beliefs to faith alone, as a purely sentimental and private affair. Still, both agreed that belief in God was not a matter of cognitive reasoning. It may have been a 
coincidence, but their rejection of natural theology and the dissociation of theistic belief from rational activities as the nascent natural sciences happened at a time when religion started to lose ground in the leading highly educated circles in Europe. And this negative intellectual attitude mainly towards Christianity in these circles ended up being at least part of a large process of secularization in those societies ${ }^{3}$. In the end, the idea that this would be a merely academic question, with no import to society or culture at large might have been wrong. It is not an easy task to trace a causal relationship between the demise of natural theology in academia and this cultural process, but we know they both started at about the same time. So, it is possible that the effort of re-establishing natural theology according to parameters of scientific reasoning has more implications than to open again to philosophy an activity that has been denied to it by mainstream authors in the last couple of centuries.

However, our concern here lies not in the historical or sociological implications of the objections raised by Hume and Kant, but whether they are philosophically justified. As we saw in the previous section, their case against natural theology involved many different arguments. In this part we are going to see how Swinburne's approach to natural theology can answer to this influential challenge.

Let us see first the problem pointed out by both that natural theology is not a legitimate intellectual activity because we do not have experience as a secure guide according to which we could discern which hypothesis is best. Without the senses we are in the dark concerning the knowledge of anything that is not purely conceptual, but the existence of God is beyond the limits of what can be reached

${ }^{3}$ For a lengthy analysis of this process, see Charles Taylor, $A$ Secular Age, 2007. 
by the senses, so it is not something we can reason about. Now, the way the objection is put here may be answered simply by saying that natural theology does not claim to have knowledge of God in a direct and empirical way, but by means of reasoning. After all, even in other contexts as daily life and scientific investigation we do not claim to know only events and substances that are directly present to our sensorial experience.

Unless you are a sceptical philosopher, who put in question the very possibility of knowing something (and this a type of position hardly found outside philosophy groups), you will agree that there are other ways of acquiring knowledge other than direct perception. You know your name because someone told you so; you know if you throw a stone into a window, it will probably break the glass. These are simple examples of day-by-day knowledge, which are only controversial in philosophical discussions, where the conceptual requirements are more rigorous, although not always wiser. Epistemologists call those sources of knowledge testimony and induction, respectively. They can certainly reveal to be problematic when you come to think of them: you could have been deceived by your parents when they told you called the way you think you are called, your birth certificate could have been falsified. The window glass could be harder than normal and did not break when the stone hit it. So, you might be wrong, despite being confident about the truth of those pieces of information. However, even if we take seriously these special types of situation regarding the mentioned examples, there is no reason to deny that generally testimony and induction are legitimate ways to acquire knowledge as well, and that they do not involve direct contact with what is being known from them.

From Hume's point of view, however, testimony is just a shortcut to perception (see Hume, An Inquiry concerning Human Understanding, section $\mathrm{X}$ ), which is the real basic 
source of information. He was a pioneer in the epistemology of testimony, an area that has increased in quantity and quality of contributions since the end of the $20^{\text {th }}$ century, mainly after the publication of C.A.J. Coady's Testimony - $A$ Philosophical Study (1992). From then on, Hume's reductionism has been rivalled by anti-reductionist conceptions, according to which testimony is an autonomous kind of knowledge, on a par with perception, memory and reasoning. It is true that I learned my name by hearing someone telling it to me or by reading it in a document, but the source of this piece of information is not my senses, but the report of someone, it is what is spoken by a person ${ }^{4}$. In this sense, testimony is not a more convenient way of acquiring knowledge that is really justified only to those who got it perceptually at first hand. Rather, there is some knowledge that is only obtainable by someone's reports or only justifiable in terms of testimony. The epistemology of testimony is now a complex and fascinating field, whose description is well beyond the limits of this article. For now, it is enough to state the possibility of testimonial knowledge, and what we really need is to understand induction better, since this is the other example alluded above in the answer to Hume's challenge, and the core of Swinburne's proposal to natural theology.

Induction is a type of reasoning. It is generally defined in contrast to deduction. The main difference between them is that while in a deductive reasoning the conclusion follows necessarily from the premises, in an inductive argument it is possible that the conclusion be false even if the premises are true. The idea is that, in a good inductive argument, the conclusion may possibly be false, but in fact it is probably

${ }^{4}$ Coady is a champion of anti-reductionism. For a more updated anti-reductionist epistemology of testimony, see Jennifer Lackey, Learning from Words: Testimony as a Source of Knowledge (2008).

Manuscrito - Rev. Int. Fil. Campinas, v. 44, n. 4, pp. 564-606, Oct.-Dec. 2021. 
true. An inductive reasoning aims to assess how probable is a hypothesis in view of a piece of evidence. This often takes the shape of a causal explanation, and is partially based on information taken for granted. So, in view of what we know about how the world works, if we throw a stone against the window, the glass will probably break. By means of induction, we can predict what is going to happen in the future or give meaning to what happened in the past. The explanatory cause could be wrong, but is probably right if it is more coherent with background knowledge and evidence than otherwise. This 'otherwise' may mean either in comparison with other explanations or in relation to the negation of the hypothesis under evaluation, depending on the context.

Swinburne's proposal for natural theology is an inductive one. He takes theism as an explanatory hypothesis and some phenomena as pieces of evidence, which are used to evaluate the probability of the thesis that there is a God. Some evidence he takes into account were part of deductive arguments in traditional natural theology. So, in the argument from design, the phenomenon of order observed in the physical world is the piece of evidence at stake. Natural order makes possible scientific knowledge, by means of which we can predict and have a relative control over some happenings. It was part of deductive arguments like the fifth of the ways by means of which Thomas Aquinas aimed to argue for the existence of God in the $13^{\text {th }}$ century:

The fifth way is taken from the governance of the world. We see that things which lack intelligence, such as natural bodies, act for an end, and this is evident from their acting always, or nearly always, in the same way, so as to obtain the best result. Hence it is plain that not fortuitously, but designedly, do they 
achieve their end. Now whatever lacks intelligence cannot move towards an end, unless it be directed by some being endowed with knowledge and intelligence; as the arrow is shot to its mark by the archer. Therefore some intelligent being exists by whom all natural things are directed to their end; and this being we call God. (Thomas Aquinas, Summa Theologiae. Part 1, Question 2, Article 3)

In the above quote, 'governance of the world' is the evidence Aquinas starts with. It means that even natural bodies, 'which lack intelligence', are ordered in a way that allows us to predict their behaviour ('always, or nearly always'). From this constancy, he concludes that this is a fact that could not be fortuitous or inexplicable, but that should have a cause that directs the events and gives order to physical objects. This order is a type of intelligence, in the sense of something that makes the physical world intelligible. Since those objects are not intelligent, the intelligence they manifest had to come from outside the natural world, and given that God is not part of the natural world, Aquinas concluded that this piece of evidence provided a way to show God's existence. Cleanthes's proposal presented in Hume's Dialogues was another deductive version of the design argument, which attempted to show that there is a strong analogy between the intelligence manifested in the physical world and human intelligence in constructing artefacts. So, there should be an artificer of the world: God.

A problem with a deductive version of the design argument, and all inferences that start with empirical evidence is that the conclusion can be denied while the premises are still considered as correct. In other words, there is no necessity linking the observed natural order and the 
alleged conclusion of God's existence. This is why Hume's strategy for discrediting the argument is producing many different alternative conclusions that could be drawn from the same premises.

In an article published in 1968, Swinburne advances some answers to Hume's criticisms to the argument of design. Firstly, he distinguishes between two types of order. On the one hand, there are 'regularities of copresence' or 'of spatial order' (Swinburne 1968, p. 200), which is a particular way in which parts of a whole are organized so that it shows positive values such as beauty, functionality and intelligence. A popular example of this is the human eye, which is compared to a machine that works well for its purpose, as the eye is efficient in providing us with visual information. In both structures, parts are arranged in a way that the whole displays positive features that are supposed to be the result of design. On the other hand, there are 'regularities of succession' or 'of temporal order', which is the general obedience of events in the physical world to a pattern of sequential steps that can be captured by natural laws. It expresses the fact that the world is not fundamentally chaotic, but that there is a configuration in it that can be discerned in mathematical models, which account for the effects that happen after a given occurrence. This is a very basic condition for the possibility of scientific activity itself.

Now, for Swinburne, the argument criticized by Hume in the Dialogues concerns to a regularity of spatial order, which is weaker as evidence to theism than the temporal order. The reason for this relative weakness is that a peculiar conformation of parts in a whole in a physical structure is a problem that can be dealt with under the limits of scientific method. This means that natural sciences may come up with an explanation for this particular phenomenon without needing to postulate any supernatural agency (Swinburne 1968, p. 201). This is exactly what happened to the analogy 
of the eye in William Paley's Natural Theology (1802), since a few decades later, an avid reader of Paley's book called Charles Darwin put forward the principles for a scientific explanation for that structure. Being simpler than theism in not postulating any being in addition to the physical world, and bearing other virtues of good science, Darwin's theory of evolution by natural selection could provide a basis for a satisfactory account not only for the functionality of the eye, but also for its deficiencies ${ }^{5}$. The whole universe is a physical structure that shows both order and disorder, which can be explained in many different ways.

Although the spatial regularity shown by the physical universe could be given many different explanations, and theism is only one of them, Swinburne is able to provide interesting replies to Hume's criticisms to that version of the design argument. One of the sharpest objections was that postulating an infinite God would not be necessary to explain a finite world, since it would be against the principle of proportioning the cause to the effect. Yet, despite the appearance, this norm is not correct, and should not be confused with a simplicity principle. One thing is to make the explanation the simplest as possible; another thing is to restrict it to what is enough to imply the effect only. This latter postulate would run counter the criterion of fruitfulness, which is common in scientific contexts, that is, the more fields a hypothesis can clarify apart from the object it aims to understand the more valuable it is. So, in postulating an infinite cause for a finite universe, the theist is doing nothing wrong, since this way her hypothesis may be able to explain other pieces of evidence as well.

${ }^{5}$ For an accessible and well written explanation of the eye structure from a Darwinian perspective, see Richard Dawkins Climbing Mount Improbable (1997). 
Another criticism made by Hume is that single entities like the observable physical universe cannot be adequately explained because we do not have instances enough from which to induce an explanation. Yet, this is a too narrow conception of induction, and the one that gives the less plausible interpretation of scientific reasoning. Instead of it, the inductive reasoning implied in natural sciences is better construed as an inference for the best explanation also called 'abduction', which does not require a great amount of individual examples in order to be properly done. In addition, if we could not do science of singular objects, then cosmology and physical anthropology could not have been developed. Still, both these natural sciences have flourished. The reason for this is that, in order to know a singular object, we need to associate it to a wider concept, so that its characteristics may be described in an intelligible way. Yet, as Swinburne says, 'nothing describable is unique under all descriptions' (Swinburne 1968, p. 208), that is, the physical universe and the human species can be described in a way that makes them analogous to other objects in the explanatory activity. So, the existence of an ordered universe or of the unique human species there are today can be explained if they are described as analogous to something else, making them another element in a set of objects under a common concept. And this is why cosmology and physical anthropology are possible and flourishing sciences, despite the fact that we do not have many other cases from which to draw an inductive generalisation. In consequence, the objection against the design argument according to which it does not work because it deals with a unique instance or object does not stand.

What about the multiplication of wild hypotheses, given that experience is not available to regulate this? Why not a finite god, polytheism, or pantheism? Why not just chance? All these questions Swinburne answers by invoking either 
the principle of simplicity mentioned above or the relatively higher capability of theism in view of these rivals in explaining the regularity of succession, which is more important and fundamental than the spatial order. As we saw, the relationship between experience and explanation choice is more complex than Hume's empiricism seemed to require. Hypotheses do not have to emerge from experience in an enumerative type of induction, since there are other more sophisticated interpretations of inductive reasoning. According to Swinburne, 'the simpler a theory, the more probable it is' (Swinburne 2004, p. 53), which is then an inductive principle too. So, wild hypotheses should not be allowed as long as being wild means being excessively imaginative, which is contrary to simplicity. Polytheism can be considered less probable than traditional theism since this one postulates one single God with infinite powers, while the former has the complexity of requiring more than a deity for the same effect. A finite god is complex in another sense. A limitation in the degree of a quality requires additional explanation why that limit instead of another one. So, the hypothesis of a finite god in the sense of having limited powers is more complex than postulating an infinite God because it demands additional explanation of why that limit to its finitude instead of another one. Attributing either zero or infinite degree of a quality requires less additional clarification, and this is why theism is simpler than the hypothesis of a finite god (Swinburne 2004, p. 55).

On the other hand, if the finite god and the pantheistic hypotheses mean an entity that is part of the physical world or coextensive with it, then they are less preferable than theism because they cannot explain the regularity of succession, since those kinds of gods would be part of the order to be explained. Theism provides an explanation for the regularity of succession by means of the intentional action of an immaterial, infinitely free, powerful and good 
person, who is not part of the physical universe. In contrast with regularities of the spatial order, which are potentially explicable by a scientific theory or by postulating a being that is part of the world, the very existence of the regularity observed in the succession of cause and effect is beyond the reach of these explanations. This applies to the chance hypothesis as well, which cannot explain the temporal order either, according to Swinburne, for 'the claim would be that there are no laws of nature which always apply to matter; matter evinces in the course of eternity all kinds of patterns of behaviour, it is just chance that at the moment the states of the Universe are succeeding each other in a regular way' (Swinburne 1968, p. 211). Yet, this is highly implausible, and would result in rendering unintelligible a metaphysical condition for scientific activity. So, at least in comparison to the hypotheses made up by Philo in Hume's Dialogues, the theistic theory has a more promising explanatory prospectus.

A last question addressed by Swinburne in his article concerns to Hume's objection that the theistic God is too mysterious to be a good explanation. This criticism may be divided in two parts. First, theism would be a defective hypothesis because it needed explaining as well. Yet, Swinburne points out that Hume provides a good answer to his own objection by denouncing it as a version of the 'completist fallacy', that is, the claim that we can only explain something when the explanation is also completely explained. This is a fallacy because if this requirement were correct almost nothing would have explanation. On the other hand, the mysterious God objection might mean that the explanation would not add any intelligibility, since an infinitely powerful mind would be as obscure as the ordered physical universe. Swinburne replies saying that in scientific theories unobservable entities are postulated to explain complex phenomena. These explanations are acceptable even so because they are simple and coherent. In other 
words, in postulating the existence of simple although unobservable molecules with a particular behaviour, chemistry is able to explain an array of observable complex phenomena, which become more coherently unified, predictable and controllable. So, again, the requirement for a good explanation is not that the entity it postulates should be observable, but that it may be intelligible in the sense of being simple and coherent, and is able to provide unity to the phenomena it aims to explain. According to Swinburne, theism meets well these criteria.

In a more recent text, Swinburne brings additional answers to Hume's criticisms, associating them to Kant's objections to natural theology. Causation is a common theme for Hume and Kant, and both refuse to metaphysics the right to apply it in arguments for the existence of God. For Hume, causality is a link we make between external objects seen in regular succession. This means that there is no necessary connection between cause and effect, but only a habit formed by constant conjunction of many observed events, which makes us believe the future will be similar to the past (see Hume, Enquiry concerning Human Understanding, Section IV). However, Swinburne argues that observation of external objects regular succession is not the only or even most evident example of causation. Our basic acts, like an intentional movement of our own arms, are much more evident as examples of caused events (Swinburne, 2012a, p. 323). It is then more probable that we acquire the notion of causation from finding that we can cause bodily movements.

So, we do not need to observe many instances of causation to acquire this notion, which means that singular causation is possible (Swinburne, 2012a, p. 324-5). Instead of Hume's causality theory, says Swinburne, in order to justify the belief that $\mathrm{A}$ is the cause of $\mathrm{B}$, many contemporary philosophers of science do not resort to observation of regular succession, but to an inference for the best 
explanation. This way, the belief that A is the cause of B is justified because $\mathrm{A}$ is the best explanation for $\mathrm{B}$. As we saw, there are some criteria for a hypothesis to be taken as the best explanation: it has to be simple, it must make the observed evidence probable, it should fit in the background knowledge, and it is expected to have a small scope. There is no reason to deny in principle that theism may comply with all these criteria. So, as a reply both to Hume and Kant, a more updated concept of causal relation does not require that the object to which it is applied in an explanation should be perceivable by the senses.

\subsection{Answering Kant}

Turning then more specifically to Kant, the additional challenge he poses regarding Hume has to do with the conception of God Kant takes into account and the type of argument this concept would require. God is the "being of all beings', 'the ideal of unlimited "all reality" (the ens realissimum)'. For Kant, we cannot show through argument that a being like this exists because this concept is beyond the limits of experience where the causal relationship could be legitimately employed. As a result, natural theology would need a strictly conceptual argument like the ontological as a basis for demonstrating the existence of God in this sense.

For Swinburne, although Kant admitted we can have concepts of non-observable objects, he also thought that the concept of cause could be applied only to objects graspable by sense experience (Swinburne, 2012a, p. 327). Yet, Kant fails to show how he knows why only some types of experience are possible, which is a problem I alluded to in the exposition of Kant's criticisms to natural theology. In connection with this, there is no reason to think that we can 
only have knowledge about things that are observable by the senses:

If a hypothesis about unobservable persons is logically possible and yields many good predictions, that is reason to suppose that it is probably true. And if the probability is high enough, we can (very probably) know that it is true. (Swinburne, 2012a, p. 329)

Put differently, as we saw previously, the hypothesis of theism could be confirmed by empirical evidence even if God cannot be accessible to sense perception. The belief in God could be justified by means of causal explanation arguments, since there is no reason to restrict causality to what is accessible to the senses. If so, although we cannot have certainty, we can have empirical knowledge about the existence of God in this sense. For Swinburne, Kant's whole conception of how empirical knowledge works would be problematic.

For him, Kant's contention that we cannot have knowledge of the unconditioned because all rival hypotheses are equally defendable is unsound. Kant purports to illustrate this with his 'antinomies of pure reason'. However, in the cases Kant uses as examples, 'evidence can often make one such principle more probable than another' (ibid.). In addition, there are two problems with Kant's thesis that we cannot have knowledge about the unconditioned because there is no way to decide among different possible explanatory theories. The first problem is that Kant talks about knowledge in terms of certainty, but human knowledge about contingent matters is fallible and is better understood if it is framed in probability and inductive terms. The second problem is that highly successful physical theories explain phenomena by means of postulating 
unobservable entities, but Kant died before he could testify this more clearly in the beginning of $19^{\text {th }}$ century. So, if he had known of their subsequent history, he might have acknowledged great scope for human reason to acquire probably true beliefs about matters far beyond the observable' (Swinburne, 2012a, p. 331). If God is beyond any possible experience, many unobservable entities in modern science are so as well, but this does not make the theories that postulate them less intellectually acceptable. Kant's criticisms to natural theology were based on a model of scientific reasoning that is no longer applicable.

Another important element in Kant's objection to natural theology is his idea that there can be only three types of argument, and that all inferences to the existence of God depend finally on the ontological argument. Swinburne rejects Kant's typology because it does not take into account the specificities of many different kinds of arguments for the best explanation that are possible. Not all conceptual arguments have the form of the ontological argument Kant analyzed, and not all empirical arguments are well described in terms of what he calls the physic-theological. So, we should better not take Kant's classification of natural theology arguments too seriously, since it is too imprecise (Swinburne 2016, p. 11).

On the other hand, as we saw, Kant centers his attacks in the ontological argument and concludes that we should abandon it. Swinburne also thinks the ontological argument should not be taken in high regard, but for different reasons. For him, in the first place, it is mostly a philosophical construction instead of having a root in the monotheistic tradition and people's religious experience (Swinburne 2004, p. 8-9). This is part of the reason why his proposal of providing a new form to natural theology is restricted to a posteriori arguments only. In doing so, he claims to be in tune with the best tradition in the argumentative discussion 
about God, which only formulated an argument as the socalled ontological in the $11^{\text {th }}$ century with Anselm. Secondly, he agrees with Kant that God is not a logically necessary being, since for him modal logical properties (possible and necessary) belong to sentences, not to beings. Like Hume, he argues that denying a sentence with the form ' $\mathrm{x}$ exists' does not imply a contradiction (Swinburne 2012b, p. 13). So, if the role played by the ontological argument was of justifying the existence of God as necessary in the logical sense and if this was needed as a fundamental ground for all natural theology arguments, then Swinburne's project would need to find another sense in which God can be considered necessary. Since this is an important element in an answer to Kantian-type objections, let's elaborate on it a little more.

\subsection{God as a necessary being and doing without the ontological argument}

For Swinburne, there is no need to grant to the ontological argument the prominence sustained by The Critique of Pure Reason. Recall that Kant held this because that argument claimed to justify the thesis that God is the supreme being, and because it would show why God should be taken as the best terminal point of a metaphysical argumentation about the foundations of reality. Now, these two problems may have different solutions. On the one hand, one may describe God's supremacy in terms of an account of necessity other than the logical one. On the other hand, the best terminus of metaphysical explanation of reality does not need to be so that its denial would be a contradiction. Instead, this unique quality of terminal cause could be justified in another way. In the remaining of this article, we are going to see Swinburne's proposal for the first problem (God as a supreme but not a logically necessary 
being) and part of his answer to the second question (why stop in God?). Another part of this answer for the best terminus of explanation problem is provided in Swinburne's theory of explanation (Swinburne, 2004), which is beyond the scope of this text.

The monotheistic tradition believes that God does not exist as a matter of contingency, but holds that $\mathrm{He}$ is real and has the properties traditionally attributed to Him necessarily, in the sense that its being is not just something that could happen or not, but rather a fact that could not be otherwise. Traditionally God is thought to be an incorporeal spirit, who is eternal, omnipotent, omnipresent, perfectly free, creator of the universe, omniscient, perfectly good and source of moral obligation. Theism holds that the properties attributed to God are essential to Him, that is, He could not exist without all of them.

The challenge of establishing the necessity of God without resorting to the ontological argument is answered by Swinburne in two steps. Firstly, he wishes to show that it is logically possible that there is a being who is essentially a deity. Being essentially something means it could not exist without the properties that characterize it. So, being essentially a deity means that, if it exists, it could not exist without the properties a deity has. Since deities are everlasting, if there is a being that is essentially a deity, this would mean that there is a being that has always existed and will always exist. There seems to be no incoherence in this concept, so we can consider the existence of a being who is essentially a deity logically possible.

The second step is then to consider in what sense it would be coherent to consider such a being a necessary being. Traditional theism says that God is omnipotent and infinitely good. God's omnipotence implies that He could 
deprive himself of His power or even of His own existence ${ }^{6}$. For Swinburne, God's continuing existence in the infinite future is justified with the idea that His action of keeping Himself in existence would be better than putting an end in His own existence or letting someone else doing it. As an omnipotent being, the only possibility of God having His existence ended in the future would be by His own acceptance of this 7 . This way God's infinite existence in the future becomes necessary in view of the combination between His omnipotence and infinite goodness.

What about his infinite existence in the past? Since there is no backward causation, God could not cause Himself to keep on existing forever in the past. However, if God is essentially omnipotent and infinitely good, this means these properties could not be lost or changed. This means that, if God is omnipotent and infinitely good essentially, He must be thought of as having these properties forever in the past as well:

${ }^{6}$ The famous 'stone paradox' (could God create a stone that $\mathrm{He}$ could not lift?) comes from this feature of omnipotence. In the paradox, both the negative and the positive answers are problematic to the idea that God is omnipotent.

${ }^{7}$ God's decision in view of His infinite goodness would also be the answer to the stone paradox: He could deprive Himself of His power depending on whether that would be the best action in the specific circumstance. So, the answer would be yes, God could deprive Himself of His power, that is, there is no force external to Him limiting His omnipotence. However, God's decision of reducing His own power in a given circumstance depends on His infinite goodness, i.e. depends on His decision for the good overall. In other words, God can create a stone like that because of His omnipotence, and may refrain from lifting it depending on His own decision regarding His essential goodness. 
If God is essentially backwardly everlastingly omnipotent and so had essentially the properties entailed by that, he would not be the same person if at some earlier time he had had less power. If a being began to be omnipotent or began to exist, he would never ever be God (Swinburne 2016, p. 249).

So, the idea is that God is essentially a being in control at all times of everything that happens, and this includes the past. A way of thinking this overall and essential supremacy is as a supreme form of all things, as the Platonic Form of Good, which determines the qualities of all beings. So, God would be the supreme cause of everything because He is the supreme form of all being. As such, God would then be in control at all times of everything that exists and happens to $\mathrm{be}$, and then the problem of His infinite existence in the past would be solved as a matter related to God's essence as the supreme form of being.

However, as the supreme form of being, we have to consider God as personal in an analogical sense only, i.e., as a person in a different sense as we normally use the word as regards human persons. Human persons are so that there could be someone else with all their same properties ${ }^{8}$. In addition of being an incorporeal person, God would not be a person in the sense human beings are, because by definition there could not be more than one supreme form of being. This means that God is not a particular person because $\mathrm{He}$ is not a personal substance among others in the sense that there cannot be any other with His same properties. Thus, as there can be only one supreme form of everything and if that

8 Human persons are substances with 'thisness', which is the possibility of existing a different substance with the same properties (see Swinburne 2016, p. 124).

Manuscrito - Rev. Int. Fil. Campinas, v. 44, n. 4, pp. 564-606, Oct.-Dec. 2021. 
is God, if God is personal, He is so in a different way as human persons are?.

As the supreme form of being, God is eternal in the sense of not being limited in time, so existing everlasting both in future and in past. Swinburne argues that the sense of eternity attributed to God would be better understood as existing forever in the past and forever in the future, but in time. This is because the monotheistic God interacts with creation, and this requires that $\mathrm{He}$ is in time. In addition, the concept of a timeless being is hardly meaningful (Swinburne 2010 , p. 10). On the other hand, differently from ordinary forms, God is causal without being instantiated in any particular substance. So, apart from being a person in analogical sense, God is form in analogical sense too (Swinburne 2016, p. 252). Although God would be personal and formal in a sense different from the ordinary one, Swinburne holds that God as a personal supreme form of being is still a coherent concept, since there is no contradiction in it (Swinburne 2016, p. 252). So, God is essentially everlasting and omnipotent, but without 'thisness' (ibid. pp. 255-6).

So, conceived as a personal supreme form of being and as essentially everlasting, God should be thought as existing eternally in the future and in the past, in case He exists. This is by necessity because otherwise (if a being had started existing in the past or ceased to exist in the future), it would not be coherent with the essence of God. Yet, the eternal existence in time is just one dimension of God's necessity. Recall that that claiming that God is a necessary being means that He does not exist just by chance. Swinburne proposes three senses for this notion and opts for one of them as the

9 Notice that, in addition to being part of a comprehension of God's necessity, this idea would be a good reply to an accusation of anthropomorphism. 
best account of this property so that this modern challenge to natural theology may be countered.

According to Swinburne, Aquinas thought that necessary beings were those which were not subject to corruption. However, God would be necessary in even a stricter sense: apart from not being subject to corruption, 'God is not causally contingent on anything else' (Swinburne 2016, p. 262). This is what he calls the weak sense of God as a necessary being. Although it explains why if there is a God, he exists eternally, it is a too weak sense because God's existence becomes a logically contingent and brute fact. On this account of necessity, it remains just a matter of fact that God exists.

The opposite of this weak account would be to hold that God is a logically necessary being. The justification for this generally comes in the form of the ontological argument for the existence of God. As we saw, however, the ontological argument was heavily criticized by Kant and there are good reasons for not accepting it as sound. Apart from the obvious fact that denying the existence of God is not contradictory, one of these reasons is that we should know the essence of God to say that He must necessarily exist because of it. Still, given the limitations of human knowledge, it is plausible to say that we do not know the full set of sufficient and necessary properties that uniquely identify God. So, because we only have a 'confused' concept of God's essence ${ }^{10}$, it is difficult to accept the ontological

10 To say that we don't know all God's essential properties does not mean it is not plausible to attribute to God the qualities traditional theism ascribes to Him. According to Swinburne, if there is a God of the kind postulated by theists, humans will not be able to understand in any way what he is like fully; but, if we cannot understand at all what he is like, there would be no difference between a theist and an atheist, and no point in worshipping God (Swinburne, 2016, p. 8). So, we must admit our 
argument (Swinburne 2016, p. 264). Instead of the ontological argument, which aims to a very strong conclusion and requires a too demanding previous knowledge, probabilistic arguments from observable phenomena are more promising as a way to show that a necessary being as God exists. So, Swinburne suggests an intermediate account.

In order to propose an intermediate account between the strong logical necessity and the weak sense of God being the cause of Himself as a contingent matter of fact, Swinburne suggests a modified version of Leibniz's principle of sufficient reason. In view of the possibility of indeterminism in nature and in free will decisions by humans, for example, the principle that 'everything must have a sufficient reason for being thus and not otherwise' sounds too strong. He recommends instead a principle according to which 'every event has some substance as its total or partial cause, that is, no event occurs unless some substance exercises causal influence to bring about the occurrence of either it or of some member of a set of alternative events (without determining which member)' (Swinburne 2016, p. 272). Hence, this version of the principle of sufficient reason is weaker than the original in two senses: it allows for partial cause and refers either to the event itself or to a set of alternative events.

Applying this weak version of the principle of sufficient reason, the intermediate account of necessity he suggests is that, instead of the existence of God being a contingent brute fact, it would be a result of being caused by his own nature (Swinburne 2016, p. 273). As the supreme form, on which

impossibility of understanding God's essence completely, but a theist should be granted to grasp at least part of His essence in a fallible, tentative way, otherwise the content of theistic belief would be empty.

Manuscrito - Rev. Int. Fil. Campinas, v. 44, n. 4, pp. 564-606, Oct.-Dec. 2021. 
all other forms depend, God could not appear or disappear. In other words, 'if there is to be an explanation of why there is a supreme form, it must be in terms of itself; it must be essentially causa sui, the cause of its own existence' (ibid. p. 274). This would have to be caused by an intrinsic property of being God, which would make inevitable that He exists. Swinburne calls it 'ontological necessity', which is different from metaphysical (or logical) necessity because it remains possible that God does not exist, i.e., the proper name 'God' might not refer to any individual reality.

Ontological necessity explains why God exists if $\mathrm{He}$ exists. So, ontological necessity explains the cause of God's existence by His own essence, which can be expressed by the sentence 'the event of God being ontologically necessary causes his own (simultaneous) existence' (Swinburne 2016, p. 276). If God exists, He is the cause of all events by definition. As a result, it is simpler to assume that $\mathrm{He}$ is also the cause of his own existence because of His essence. So, God would be his own cause because of his essence:

It looks very improbable that the biggest event of all is causeless, while causality governs everything else. So, mysterious though ontological necessity is, any theory of the universe, not just theism, would seem to need to postulate it (Swinburne 2016, p. 277)

The mystery of God's ontological necessity is due to the limitation of our knowledge of His essence, but it is also analogous to the difficulty in understanding why some particles are also waves, instead of being only particles - they are similar in the sense of seeming to be beyond our capacity of grasping the essence of reality. Ontological necessity is not the answer to 'why there is something instead of nothing?', 
but to 'why the existence of something is not just a matter of fact?'. The concept of God - as essentially a supreme form of being, as omnipotent and infinitely good, and as eternal (through all times in the past and in the future) - answers the question of why God exists if he exists. Employing a weak version of the principle of sufficient reason, the answer is that it is simpler to consider God as not only the cause of the existence of everything apart from himself, but as the cause of his own existence. This is necessary because stems from His own essence. However, it is not logical necessity, because it remains coherent to say that God does not exist.

So, contrary to what postulated Kant, we do not need the ontological argument at all to justify God's necessity. In addition, since Swinburne's meaning of God's necessity is conditional to God's existence (God is necessary if He exists), the job of showing that God exists should be done by inductive arguments for the best explanation.

\section{Concluding Remarks}

In this article, I attempted to describe the main arguments by Hume and Kant against natural theology, which were very influential in the $19^{\text {th }}$ and $20^{\text {th }}$ century academic philosophy. The aim was not historical only, but to serve as a starting point for the introduction of Richard Swinburne's main traits of the new form he proposes to this traditional philosophical activity in terms of inductive probabilistic arguments.

My contention was that the criticisms by Hume and Kant as construed above do not justify the idea that natural theology is not a legitimate field of philosophical enquiry anymore, particularly since the modern scientific revolution. I hold that Swiburne's responses to their objections are based on a more updated philosophy of science than the one they seemed to presuppose, particularly the relationship 
between experience and theory, the role of necessity in explanation, and the place of metaphysics in an age of science.

With this kind of proposal, Swinburne went against the mainstream in the main current academic circles in the 1970's, where theism had fallen in disrepute since the $18^{\text {th }}$ century as a metaphysical theory. The success of natural sciences in the description of physical reality, and the idea that they were based on sense evidence was associated to that decline. Logical positivism was an expression of this position, and it is not totally implausible to see Hume's and Kant's criticisms as in the root of that rejection of metaphysics. The decline of logical positivism opened the way for a return of the metaphysical debate in contemporary philosophy. Richard Swinburne along with authors such as Alvin Plantinga, William Alston and John Hick helped to restore the respectability of theism as a metaphysical theory. His proposal is certainly not destitute of controversial parts, but this is different to say that it belongs to an activity that no longer has a place in philosophy.

\section{References}

COADY, C.A.J. Testimony - A Philosophical Study. Oxford: Clarendon, 1992.

DAWKINS, Richard. Climbing Mount Improbable. New York/London: W.W. Norton, 1997.

HUME, David. Dialogue concerning Natural Religion. Edited by Stanley Tweyman. London: Routledge, 1991 [1779].

KANT, Immanuel. Critique of Pure Reason. Translation by Norman Kemp Smith. London: Macmillan, 1952 [1781/87]. 
KANT, Immanuel. Critique of Practical Reason. Translation by Werner Pluhar. Indianapolis, IN: Hackett Publishing, 2002 [1788].

KANT, Immanuel. Religion within the Limits of Reason Alone. Translation by Theodor Greene. New York: Harper \& Row, 1960 [1794].

LACKEY, Jennifer Learning from Words: Testimony as a Source of Knowledge. New York: Oxford University Press, 2008.

LEIBNIZ, Gottfried. Monadology. In: STRICKLAND, Lloyd. Leibniz's Monadology - A New Translation and Guide. Edinburgh: Edinburgh University Press, 2014.

PALEY, William. Natural Theology or Evidence of the Existence and Attributes of the Deity, collected from the appearances of nature. Oxford: Oxford University Press, 2006 [1802].

SWINBURNE, Richard. The Coherence of Theism - Second Edition. Oxford/New York: Oxford University Press, 2016.

SWINBURNE, Richard, 'Why Hume and Kant were mistaken in rejecting natural theology'. In: Th. Buchheim \& F. Hermanni \& A. Hutter \& Ch. Gottesbeweise als Herausforderung für die moderne Vernunft. Tübingen: Mohr Siebeck, 2012a, pp. 317-334.

SWINBURNE, Richard. 'What Kind of Necessary Being Could God Be'. In: European Journal for Philosophy of Religion, 4/2 (Summer), 2012b, pp. 1-18.

SWINBURNE, Richard. Is There a God? - Revised Edition. Oxford: Oxford University Press, 2010.

SWINBURNE, Richard. The Existence of God-Second Edition. Oxford: Oxford University Press, 2004. 
SWINBURNE, Richard. 'Intellectual Autobiography'. In: PADGETT, Alan. Reason and the Christian Religion. Oxford: Clarendon, 1994, pp. 1-18.

SWINBURNE, Richard. 'The Argument from Design'. In: Philosophy - The Journal of the Royal Institute of Philosophy. Vol. XLIII, No. 165, 1968.

TAYLOR, Charles. A Secular Age. Cambridge, MA: Harvard University Press, 2007.

$(\mathrm{Cc}) \mathrm{EY}$ 